\title{
Interest Savings of the Hungarian Budget between 2013 and 2019 in Comparison with Other EU Countries*
}

\author{
Gergely Kicsák - Dávid Benkő - Noémi Végh
}

This paper compares the decline in government interest expenditure in Hungary and other Member States of the European Union. Government interest expenditure decreased across the whole EU between 2013 and 2019, and the second largest drop was recorded in Hungary, with government interest payments diminishing from 4.5 per cent of GDP to 2.3 per cent. To understand the cause of this development, favourable even by EU standards, the change in interest expenditure was divided into three main factors: the yield and interest effect, the impact of the change in the debt ratio and the influence of foreign currency debt. The analysis showed that the decrease in Hungarian expenditures can be attributed mostly - by about 80 per cent - to declining domestic yields, while the fall in the debt ratio had a somewhat lesser effect - around 18 per cent. Had foreign currency debt levels been lower, Hungary's interest expenditure would have shrunk even more.

Journal of Economic Literature (JEL) codes: E42, H50, H62, H63

Keywords: general government, interest expenditure, monetary policy

\section{Introduction}

The study examined the general government's accrual-based interest expenditure in the European Union between 2013 and 2019. The analysis sought to identify the factors that contributed to the drop in interest expenditure in the different countries. The authors also wished to assess Hungary's reduction in expenditure by international comparison. Among European Union Member States, the contraction in interest expenditure was the second highest in Hungary during the period under review, reaching 2.2 per cent of GDP. To understand the reasons behind

\footnotetext{
* The papers in this issue contain the views of the authors which are not necessarily the same as the official
} views of the Magyar Nemzeti Bank.

Gergely Kicsák is a Head of Department at the Magyar Nemzeti Bank. Email: kicsakg@mnb.hu Dávid Benkő is an Economic Analyst at the Magyar Nemzeti Bank. Email: benkod@mnb.hu Noémi Végh is an Analyst at the Magyar Nemzeti Bank. Email: veghn@mnb.hu

The authors wish to thank Gergely Baksay, Balázs Csomós, Gábor P. Kiss and Dániel Babos for their valuable comments during the preparation of the study. Any mistakes are the authors' own.

The Hungarian manuscript was received on 12 June 2020.

DOI: http://doi.org/10.33893/FER.19.4.526 
this favourable place in the rankings, the main driver of the reduction should be examined. By using a method similar to the debt decomposition employed by Kicsák (2017), the change in interest expenditure from one year to the next was divided into three main factors for all EU Member States (Annex, Table 1). These three primary factors are the yield and interest effect, the impact of the change in the debt ratio and the influence of foreign currency debt. The results attest that the yield and interest effect has the greatest explanatory power among the factors, as it explains around 80 per cent of the reduction in interest expenditure in Hungary between 2013 and 2019, whereas on average, across the EU, almost 100 per cent of the drop in interest expenditure is explained by the contraction in yields. Therefore one might argue that the fall in government interest expenditure is due to the decrease in yields on the government securities market on account of the central bank programmes, the favourable macroeconomic developments and the international abundance of liquidity in recent years. The reduction in the debt ratio explains approximately 18 per cent of the interest savings relative to GDP, which could have been even higher if the foreign currency debt had been lower.

Chapter 2 provides an overview about the relevant background in literature. The following Chapter 3 presents the development of interest expenditure in Hungary and the EU, as well as the annual and cumulative interest savings since 2013. Chapter 4 gives a brief description about the methodology analysing the reasons behind the decrease in interest expenditure, before turning to the detailed discussion of the findings in Chapter 5, where the effects of the three factors influencing interest expenditure are examined in an international comparison. The chapters after that present the three main effects one by one, placing them in context within the European Union. In the final chapter, the conclusions are drawn.

\section{Overview of literature}

The study is based partly on Kicsák (2017), which examined the development of interest expenditure in Hungary between 2000 and 2015, focusing mainly on the relationship between the decrease in yields and interest expenditure between 2013 and 2015. The paper finds that in the CEE region, the interest expenditure relative to GDP shrank the most in Hungary, by 0.8 percentage points, between 2008 and 2015. The emergence of the favourable yield environment that facilitated the reduction was supported heavily from 2013 by the central bank programmes, i.e. the interest rate cuts, as well as the Self-Financing Programme mitigating Hungary's external vulnerability. Based on an analysis similar to the methodology employed in this study, the paper considers the change in yields to be the largest factor in the drop in interest expenditure, followed by the change in the debt ratio and the effect of foreign currency debt. This study breaks down interest expenditure into factors not only for Hungary, but also for the entire European Union, and the change in yields 
has been expanded with non-market loans to capture the effect of the emergency loans from the IMF and the ESM. This is expected to reduce the amount of other, uncategorised effects in Kicsák (2017).

Earlier studies include Izák (2009), which examined the development of the primary budget balance and government debt of post-Soviet countries and also presented the effect on debt of real interest rates, among other fiscal variables. That paper finds that, with the exception of Poland, post-Soviet countries were able to stabilise their debt-to-GDP ratios appropriately, even with a negative primary budget balance. However, in Poland, this stabilisation could only occur with a positive primary budget balance, as the real interest rate exceeded GDP growth between 1999 and 2006.

The analysis of fiscal policy's sustainability is often based on the sustainability of government debt. In the literature on fiscal sustainability, the seminal paper by Blanchard (1990) starts with the budget constraint. According to the definition, the present value of future budget surpluses should equal the present debt. In such a scenario, one cannot determine whether the present fiscal policy is sustainable, because the above requirement is also met with a subsequent adjustment, as noted by Tóth $G$. (2011). In his study, Tóth $G$. analyses the sustainability of Hungarian government debt, and divided the period between 1999 and 2010 into three economic policy phases based on debt dynamics and its reasons. In the period between 1999 and 2001, government debt declined by almost 10 percentage points owing to economic growth and the primary budget balance. The increase in the debt ratio in excess of 13 percentage points between 2002 and 2006 was mainly caused by the negative primary budget balance and high real interest rates, which was only partly offset by economic growth. By the end of the third period (20072010), which also includes the early years of the 2008 global economic crisis, debt climbed by another 15 percentage points or so to over 80 per cent of GDP. What is more, this growth happened in the context of a neutral primary budget balance effect, mainly on account of the economic downturn and high real interest rates.

Tóth G. (2014) analysed the sustainability of public finances based on the data from 27 Member States of the European Union. The author used past data to test five different methods as to how effective they were in forecasting the unsustainability of the budget. The main finding of the paper was that the forecasting ability of the methods was limited (with the exception of the primary budget gap), probably due mainly to the impact of the variables outside fiscal policy. The author also pointed out that the outcome of the individual forecasts depended heavily on the choice of econometric methods.

The analyses on debt sustainability focus not only on debt levels but also on their structure as well as debt management. In his study, Panizza (2008) underlined that 
besides total government debt, the development of the ratio between external and domestic debt was also important. He also stressed the importance of the structure of debt. According to Guscina (2008), political stability is important, just like an appropriate institutional background and a sound macroeconomic environment, because these form the basis for the development of the domestic government securities market. The most important consequence of this is the rising demand for long-term bonds denominated in the domestic currency, which allows the average term to maturity of government debt to be extended. As the maturity extends, the annual gross financing need diminishes, which considerably reduces countries' financing risk. Das et al. (2010) examined the relationship between the level of debt, debt management and financial stability. The authors claim that debt management can mitigate risks through buybacks, switch auctions and derivative transactions, moreover the investor base should be diversified and floating-rate bonds should be issued.

Hemming and Petrie (2000) developed a multivariate framework for measuring fiscal vulnerability. Their analysis classified indicators into seven categories, including those describing the initial fiscal position (e.g. deficit, government debt), expenditure and revenue indicators (e.g. the value of transfers relative to GDP, distribution of revenues). They also took into account the indicators measuring short-term risks on government debt (e.g. the foreign currency ratio of the debt) as well as those measuring long-term risks (e.g. the change in debt in the next five years). The authors' analysis also included variables describing the implementation of the budget as well as indices on the government's efficiency, thereby incorporating institutional characteristics in the study.

Baksay et al. (2012) examined the relationship between debt financing and FX reserves, finding that $\mathrm{FX}$ issuance may have a major impact on increasing $\mathrm{FX}$ reserves, and it apparently incurs lower interest expenses for the government, but the situation is far from favourable at the level consolidated with the central bank. The paper states that under the circumstances at that time, the savings derived from the lower interest rates on the foreign currency debt were offset by the net interest losses sustained by the central bank, caused by the interest difference between the additional liquidity arising from the FX conversion and sterilised at the base rate on the one hand, and the FX placed in the FX reserves invested at a lower rate on the other hand. Therefore in the case of foreign currency debt, the interest saving of the state is offset by the deterioration in the central bank's profits.

Turner - Spinelli (2012) analysed the difference between the interest rate on government debt and economic growth ( $r-g)$, from the perspective of fiscal sustainability. They found that this difference was quite low in the 2000s relative to the 1980s and 1990s, partly because of the low volatility of inflation and the credible and low inflation targets. The authors argue that with a given primary 
budget balance and initial debt ratio, the greater the difference between interest rates and growth, the greater the change in the debt-to-GDP ratio.

The Bundesbank (2017) examined the interest expenditures of euro area countries, specifically Germany. It found that interest savings in the euro area were close to 9 per cent of GDP between 2008 and 2017. From the perspective of this analysis, one particularly relevant result of the study is that the development of interest expenditure was mainly determined by the change in yields. Germany saw its interest expenditure relative to GDP decline from 3.5 per cent of GDP to below 1.5 per cent between 1995 and 2016, facilitated by the considerable, 5 percentage point, drop in yields, despite the growing debt. In several euro area countries, while debt rose between 2000 and 2015, government interest expenditure decreased.

Lentner (2015) examined the overhaul of the Hungarian public finance system in the wake of the 2008 crisis. The author found that growth and the stabilisation of the financial system were supported from 2010 by the governance model based on burden-sharing and state engagement in the economy, and from 2013 by the unconventional monetary policy. Financing costs were reduced considerably by the Magyar Nemzeti Bank's (the Central Bank of Hungary) rate-cutting cycle that started in 2012, the Funding for Growth Scheme launched after that, as well as the SelfFinancing Programme. Matolcsy (2019) reached similar conclusions in his analysis of the Hungarian monetary policy environment and fiscal developments. He argued that the consolidation of the budget deficit and the stimulation of economic growth pointed towards a reduction in government debt, and the monetary easing from 2013 had a favourable effect on the general government's interest expenditure through the fall in government securities market yields.

\section{Change in interest expenditure and main reasons behind it in an international comparison}

The Hungarian government's interest expenditure dropped from 4.5 per cent of GDP to 2.3 per cent between 2013 and 2019 (for more details, see Kicsák 2017), which was the second largest contraction in the EU. This means annual Hungarian interest expenditure diminished by almost half in this period, which played a huge part in the reduction of government debt as well. The results of this study show that the yield and interest effect and the impact of the debt ratio explain over 80 per cent and around 18 per cent of the decrease in interest expenditure in Hungary, respectively, which would have been even greater had the amount of foreign currency debt been lower. Moreover, interest expenditure declined in Hungary while the share of domestic funds within debt financing increased considerably.

The interest expenditure of the Hungarian budget shrank significantly, by almost half, between 2013 and 2019, therefore the state's interest savings amounted to 
2.2 per cent of GDP in 2019 (Figure 1). The coordinated operation of the two main branches of economic policy supported the reduction in interest expenditure from 2013. Independent monetary policy and the central bank's innovative and targeted instruments effectively supported sustainable public finance developments in cooperation with fiscal policy (Matolcsy - Palotai 2018). The positive impact of this coordination led to a decline in the government's interest expenditure, alongside results in several other areas of the economy. As shown later in more detail, the large savings are mainly attributable to the drop in yields, and partly to the reduction in the debt ratio, which is continuously supported by lower interest expenditure, creating a feedback loop.

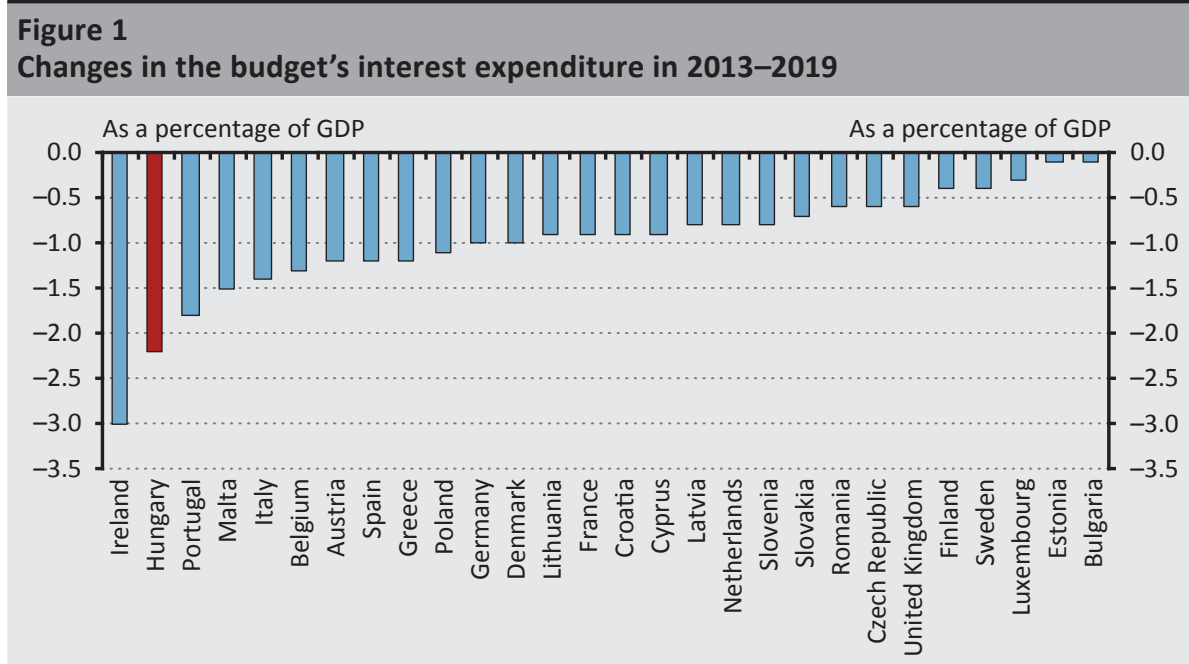

Source: Eurostat

The Hungarian reduction in expenditure was only outstripped by Ireland, mainly on account of Irish GDP growth. Many international corporations, chiefly large IT firms, moved their registered address to Ireland due to the favourable tax conditions. In 2015 Ireland's GDP increased by over 25 per cent, and it grew by over 8 per cent three times in 2013-2019; this is mostly attributable to the fact that large corporations moved there, and partly to the Irish economy's own growth.

Another interesting example is the case of Portugal, the country with the third largest drop, and Greece, where interest expenditure decreased due to the favourable rates on loans as part of the EU-IMF bailout package. Since the items with market rates make up a small share of the Greek government debt, the whopping reduction of market yields had a smaller effect. From the perspective of interest expenditure relative to GDP, the low interest on international loans 
was partly offset by the demand-constraining effect of the fiscal adjustment set as a precondition for the bailout packages, and this played a large part in the fact that the Greek economy's real output declined in three years during the period under review.

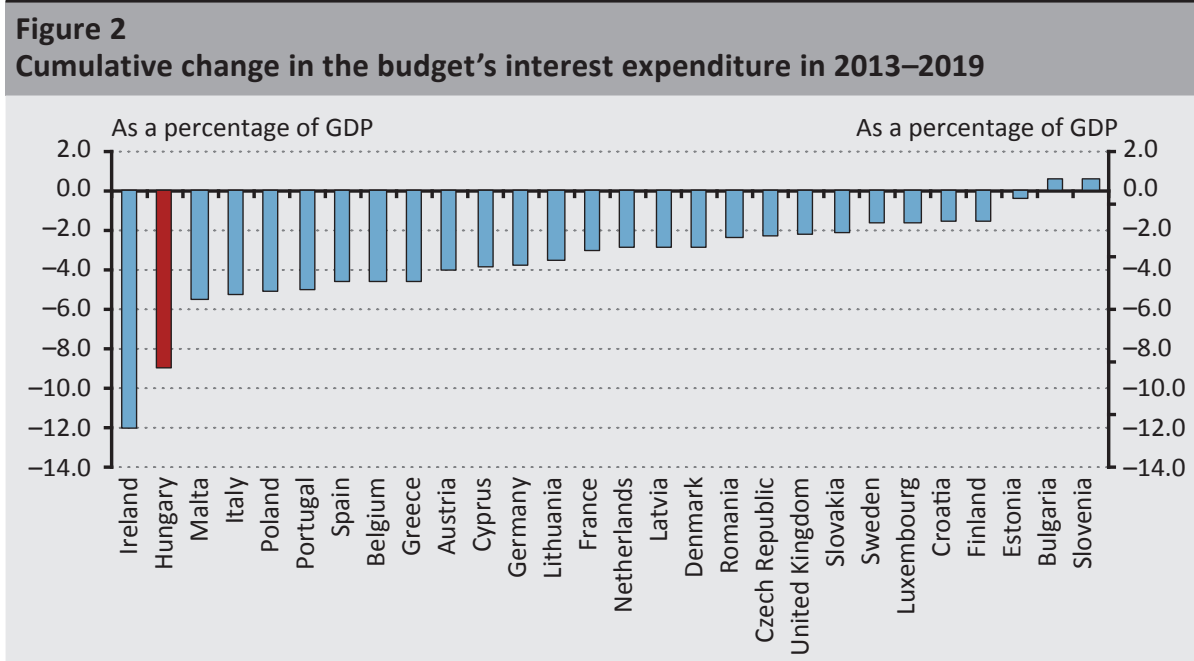

Source: Eurostat

The government's interest savings amounted to 9 per cent of GDP in Hungary, with only the Irish figure coming in higher, at 12 per cent of GDP (Figure 2). The cumulative savings illustrate the positive debt spiral that is also exemplified by Hungary. The essence of this positive spiral is that the decline in interest expenditure makes a marked contribution to the reduction in government debt, then the decreasing debt affects interest expenditure, thereby reducing the costs of debt servicing even more. The new model used in Hungarian economic policy after 2010 and the central bank's rate-cutting cycle and its Self-Financing Programme contributed to the improved sustainability of the budget significantly, through the fall in yields and the steady reduction of the government debt (Kicsák 2015).

The examples mentioned here show that different developments were the main drivers of the change in expenditure in each country. To identify these drivers and to understand what caused the substantial drop in interest expenditure in Hungary, which stands out by international comparison, the change in interest expenditure was divided into three main factors: the yield and interest effect, the impact of the change in the debt ratio, and the influence of foreign currency debt (Figure 3). 


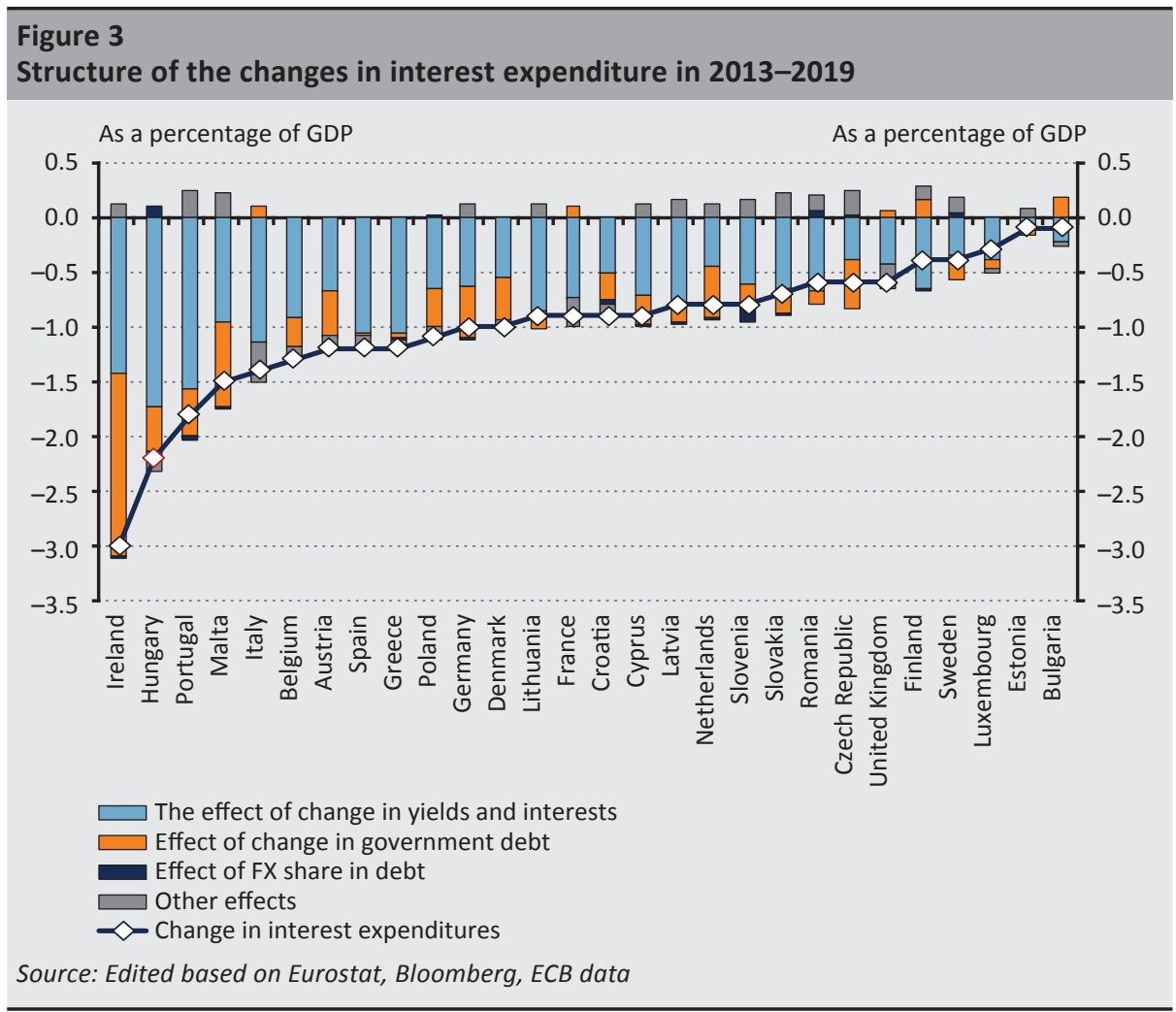

The breakdown shows that in the EU countries, the contraction in interest expenditure was influenced the most by the change in yields and interest rates, in turn resulting from the global economic growth, the abundance of liquidity and loose monetary conditions in Europe (and the whole global economy). At the outbreak of the 2008 economic crisis, the European Central Bank (ECB) responded with quick rate cuts, however, it only started government bond purchases to reduce the interest rate spreads of Mediterranean countries in 2010 (Csutiné et al. 2017). Due to its size, however, the programme was only able to halt the rise in the spreads, no sustained fall in yields was achieved, which contributed to preserving the high government debt ratios in southern countries (Matolcsy - Palotai 2018). In several countries, it can also be observed that the expenditure-reducing effect of the change in yields and interest rates is coupled with an almost neutral, or even expenditure-increasing effect of the debt ratio. In other words, the low interest rate environment concealed the negative effects arising from the stagnation or growth of the debt ratio in this period. This may even pose a risk later on, because when yields grow, the countries that were unable to lower their government debt considerably in 2013-2019 may see a rise in interest expenditure coupled with a sudden deterioration in the budget balance. This may push these countries into a negative debt spiral, and crisis management may also place a much greater burden 
on the budget and its sustainability. Hungary faces no such risk thanks to the steady and sustained debt reduction in recent years.

\section{Simplified presentation of methodology used to decompose change in interest rates}

Building on the debt decomposition methodologies, the analysis sought to examine the change in interest expenditure through the years by capturing three macroeconomic factors separately within the change. The decomposition was based on Kicsák (2017), however, the tools used there were updated, with enhancements and expansions in several respects, to make them suitable for examining all EU countries with some simplifications.

The effect of the change in yields and interest rates was measured using the benchmark yields available for each country. If the change in the yield $(r)$ is calculated for the debt denominated in the domestic currency ( $\left.D^{D O M}\right)$ and expressed as a percentage of GDP, in theory that should give the effect of the yield change in the given year $\left(e f f_{\Delta r}\right)$. However, government debt does not immediately pay the given year's yield, because the time it takes for the different debt items to be repriced to the new yield level varies. Therefore the yield change has to be adjusted for this repricing time. Due to the debt profile of the different countries, the pace of repricing may vary across countries and even at different times, however, due to the lack of data, and as a simplification, the Hungarian repricing pace was used. Thus a sensitivity analysis was performed for the pace of repricing, and it was found that even if another pace was used, no material difference would be detected in the results. The analysis also took into account the fact that the EU-IMF bailout packages also affect interest expenditure, which partly conceals the impact of the yield change in these countries. The formula from Kicsák (2017) was updated and parametrised for the current period and country group during the quantification of the yield effect, and the weights of the repricing pace were re-estimated.

$$
e f f_{\Delta r}=\sum_{i=0}^{6} \frac{\left(r_{t-i}-r_{t-i-1}\right) \cdot D_{t-i}^{D O M}}{G D P_{t-i}^{n o m}} \cdot \frac{x_{i+1}}{100}
$$

where $x$ is the extent of repricing in each year and $x=[33,13,11,10,10,9,14]$.

The impact of the change in the debt ratio $\left(e f f_{\Delta D_{-} r a t e}\right)$ is the product of the difference between the debt ratio in the given year and the preceding year on the one hand and the given year's implied interest rate $\left(I_{t}^{i m p}\right)$ on the other. The implied interest rate for the given year is calculated as the ratio of the nominal interest expenditure in the given year and the nominal debt in the preceding year. The change in the debt ratio was revisited, simplified and improved in several respects compared to the measure used in Kicsák (2017), and it is now applicable to all EU countries. The 
analysis estimates the effect of the change in government debt in a single step, in contrast to the earlier study, where it was estimated broken down into three factors (real growth, GDP deflator, nominal debt dynamics). The authors believe that the change in the debt ratio does not need to be broken down into three parts to estimate an effect.

$$
\begin{gathered}
\text { eff } f_{\Delta D_{-} \text {rate }}=\left(D_{t}^{\text {rate }}-D_{t-1}^{\text {rate }}\right) \cdot \frac{I_{t}^{\text {imp }}}{D_{t-1}^{\text {nom }}}, \\
\text { where } I_{t}^{i m p}=\frac{I_{t}^{\text {nom }}}{D_{t-1}^{\text {nom }} .}
\end{gathered}
$$

The interest rate effect of the foreign currency debt (eff $f_{-D}$ ) can be calculated by multiplying the difference between the value of the current year's foreign currency debt $\left(D_{t}^{F X}\right)$ at the given year's exchange rate and the preceding year's exchange rate $\left(X_{t}\right.$ and $\left.X_{t-1}\right)$ with the implied interest rate $\left(I_{t}^{i m p}\right)$, which is the difference between the FX interest expenditure payable in the given year and the value of the FX interest expenditure in the given year at the preceding year's exchange rate. This is then expressed as a percentage of nominal GDP $\left(G D P_{t}^{n o m}\right)$. The formula is also based on the methodology used in Kicsák (2017), however, similar to the formula quantifying the effect of the change in the debt ratio, the formula from there is simplified and improved to a great degree here:

$$
e f f_{F X_{-} D}=\frac{\left(D_{t}^{F X}-D_{t}^{F X} \cdot \frac{X_{t-1}}{X_{t}}\right) \cdot I_{t}^{i m p}}{G D P_{t}^{\text {nom }}} .
$$

\section{Effect of the changes in yields and interest rates on interest expenditure}

The above methodology shows that the change in government securities yields and lending rates reduced the government's interest burden in all countries under review. Hungary's interest expenditure declined by 1.73 percentage points as a result of the yield and interest rate changes in the period under review, putting Hungary first among European Union Member States in the ranking based on the change in yields and interest rates (Figure 4). The development of Hungarian yields was influenced favourably by the coordinated operation of the two branches of economic policy. The independent monetary policy was able to use rate-cutting cycles to adequately and steadily push government securities market yields down, while the targeted central bank measures, such as the Self-Financing Programme, had a positive effect on the structure of government debt. The growth-stimulating fiscal policy placed the Hungarian economy on a growth path far outstripping the average of EU and developed countries (Matolcsy - Palotai 2019). Moreover, the favourable international environment, international growth and the abundance of 
liquidity on money and capital markets all contributed to the decrease in yields on the Hungarian government securities market. Nevertheless, the positive yield effect was indirectly reduced by the large share of foreign currency-denominated debt, because on account of the longer maturities and the limited room for manoeuvre in FX debt management only a smaller portion of the holdings was repriced to the more favourable domestic yield level, while the rates on foreign currency debt remained high.

\section{Figure 4 \\ Change in average government securities market yields and estimated effect of the change in yields and interest rates on interest expenditure, 2013-2019}

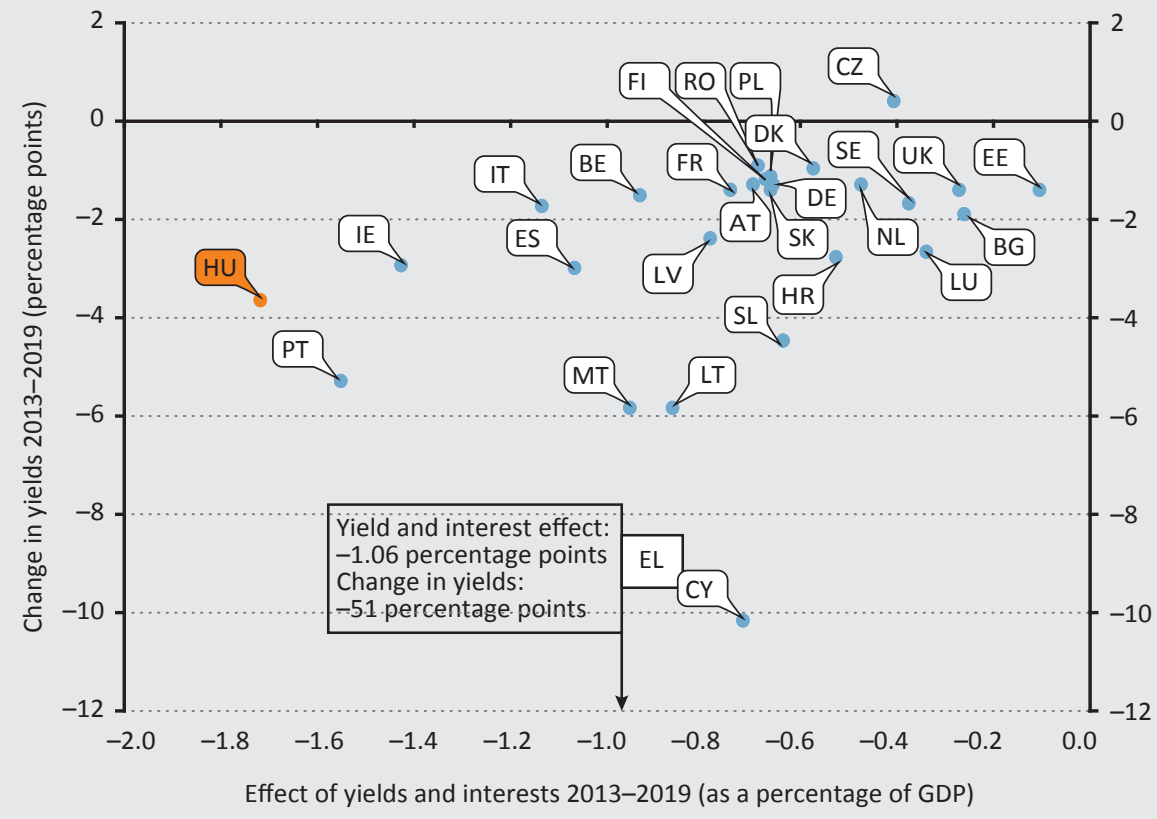

Note: We marked the countries with two-digit codes for the sake of transparency.

Source: Edited based on Eurostat, Bloomberg, ECB data

While estimating the yield and interest effect, the analysis took not only the change in market yields into account: the repricing of government debt, in other words, the time when the effect of the given yield change actually takes hold, was also considered after the change in weighted average benchmark yields was determined. Furthermore, efforts were also made to take the change in the rate on non-market loans into consideration. This was achieved by quantifying the effect of the change in yields, then the unexplained part was used to estimate the interest impact of outstanding loans and EU, IMF and World Bank bailout packages. The non-linear relationship between average market yields and the estimated yield and interest effect emerged by taking several factors into account (Figure 4). 
Interest expenditure was considerably reduced in several countries by the emergency loans provided by international organisations at much more favourable rates than market yields. These loans fixed the interest expenditure of the countries receiving the bailout at a low level, therefore no major drop in yields is reflected in the interest expenditure between 2013 and 2019 (best exemplified by Greece in Figure 4), and the impact of the skyrocketing yields during the crisis (which is not covered by the analysis) cannot be observed either. These types of package may have improved the ranking of Greece, Portugal, Ireland, Spain, Latvia, Cyprus and Romania in the ranking in Figure 1, while Hungary prepaid its IMF loan taken out in 2008-2009 at the beginning of the period under review, and 2016 saw the settlement of the loan from the EU as well. Hungary's position was not improved by the interest payment on the EU loan either, because for the most part in the period under review, the fixed euro-denominated interest on the EU loan was higher than the interest rate available to Hungary on the forint market at that time. The prepayment of the IMF loan not only provided interest earnings but also helped extend the residual maturity of the government debt, because the government financed the loans that would have matured within 2-3 years mainly by issuing long-term, 5-10-year securities. In 2013-2019, as a result of the low-interest loans facilitated by the bailout package, interest expenditure shrank the most in Greece, which had come close to a state bankruptcy.

\section{Effect of emergency loans on interest expenditure}

The IMF credit line and the European Union's financial stability funds provide financing at low interest to countries in dire financial straits for external or domestic reasons. This is often necessary precisely because of the rise in government securities market yields that occurs due to the sudden spike in CDS spreads, since the increase in interest expenditure may push the budget into a negative spiral. The bailout packages most often provide a credit line at much better rates than those available on the market, and debtors need to repay the loans at medium-term maturities. To access the IMF credit line, beneficiary countries need to make comprehensive economic policy commitments, with the primary objective of resolving the state's financial difficulties and gradually enabling it to repay the loan.

The European Stability Mechanism offers low-interest emergency loans to euro area countries to manage the funding risks arising in the fiscally heterogeneous currency union, thereby stabilising the euro area when necessary. The ESM has provided emergency loans to five countries, enabling Greece to make interest savings of over 5 per cent of GDP and Cyprus to secure savings of almost 2 per cent of GDP until 2016 (ESM 2017). However, in the case of Spain, Ireland and Portugal, this figure was below 1 per cent of GDP. Since Greece was in the deepest 
economic crisis among the five countries, it can be stated that the higher the market yields that jump due to the CDS spreads, the greater the interest savings available by utilising a preferential emergency loan.

Hungary has requested a drawdown (stand-by) credit line from the IMF under the Stand-By Arrangement several times since the 1980s. The largest one was the latest, starting in November 2008 and amounting to over SDR 10 billion, which was part of a complex loan arrangement, partly financed by the European Union and worth EUR 19 billion. The credit line was mainly necessitated by government securities market turbulences, the unstable capital position of the financial sector and the low levels of the central bank's foreign currency reserves. In the end, Hungary withdrew EUR 14.3 billion from the total amount, and it repaid the loan in full in April 2016. This made Hungary the first to repay its loan among the countries that took out crisis management loans for funding purposes at the time of the 2008-2009 crisis. The repayment of the loan reduced the foreign currency ratio and foreign ownership within government debt, and the entire funding of Hungary's debt was placed on a market footing. Alongside the reduction in vulnerability, the Hungarian central bank's rate cuts and the Self-Financing Programme introduced in a moderate inflation environment, the disciplined fiscal policy, the drop in the CDS spread and the accommodative external environment reduced Hungarian yields to below the interest on the EU and IMF loans, making debt financing even cheaper (Kicsák 2016).

According to the calculations, the yield and interest effect is around 0.5-1.5 per cent of GDP in most countries, and it is only higher in Hungary and Portugal. This figure is lower than 0.5 per cent of GDP in the Netherlands, the Czech Republic, Sweden, the UK, Luxembourg, Bulgaria and Estonia. In the Czech Republic and the UK, the low effect is attributable to the small drop in yields, while the low values in Estonia, Luxembourg and Sweden are explained by the large amounts of non-market funds obtained, as loans make up around 30 per cent of the debt in the two latter countries and almost 90 per cent in Estonia, which may slow down the repricing of government debt to a low yield level as the interest is fixed for a long term.

\section{Effect of the debt ratio on the interest rate}

Besides the change in yields and interest rates, the other major factor influencing interest expenditure is the development of government debt. The interest rate effect of the debt ratio essentially shows the combined effects of several macroeconomic developments. These include the real growth of the economy and the effect of the GDP deflator, which together produce nominal growth. The impact of nominal debt also takes hold through this effect, and within that the revaluation of foreign 
currency debt is another important factor. The analysis examines the change in the debt ratio, which captures all these factors, as well as its effect on interest expenditure, since the most important measure of government debt is the debt-toGDP ratio (also included in the EU's fiscal rules), which compares countries' output to their indebtedness.

EU countries' indebtedness declined in the period under review because the debt-toGDP ratio calculated with the weighted average of the Member States diminished from over 86 per cent to around 79 per cent, and 23 out of 28 countries saw their government debt decrease. Owing to the continuous contraction in the Hungarian debt ratio since 2011, it was around 13 percentage points lower than the EU average at the end of 2019. This places Hungary around the EU average in terms of the debt ratio's size. In the CEE region, the Hungarian figure is lower than in Croatia, and higher than in Slovenia, Slovakia, Poland, Romania and the Czech Republic (Figure 5).

Government debt in Greece, Italy and Portugal was well over 100 per cent of GDP, and exceeded 175 per cent in Greece. By contrast, government debt amounts to merely around 20 per cent of GDP in Luxembourg and Bulgaria, and it amounts to roughly 8 per cent of GDP in Estonia, the country with the lowest amount of debt.

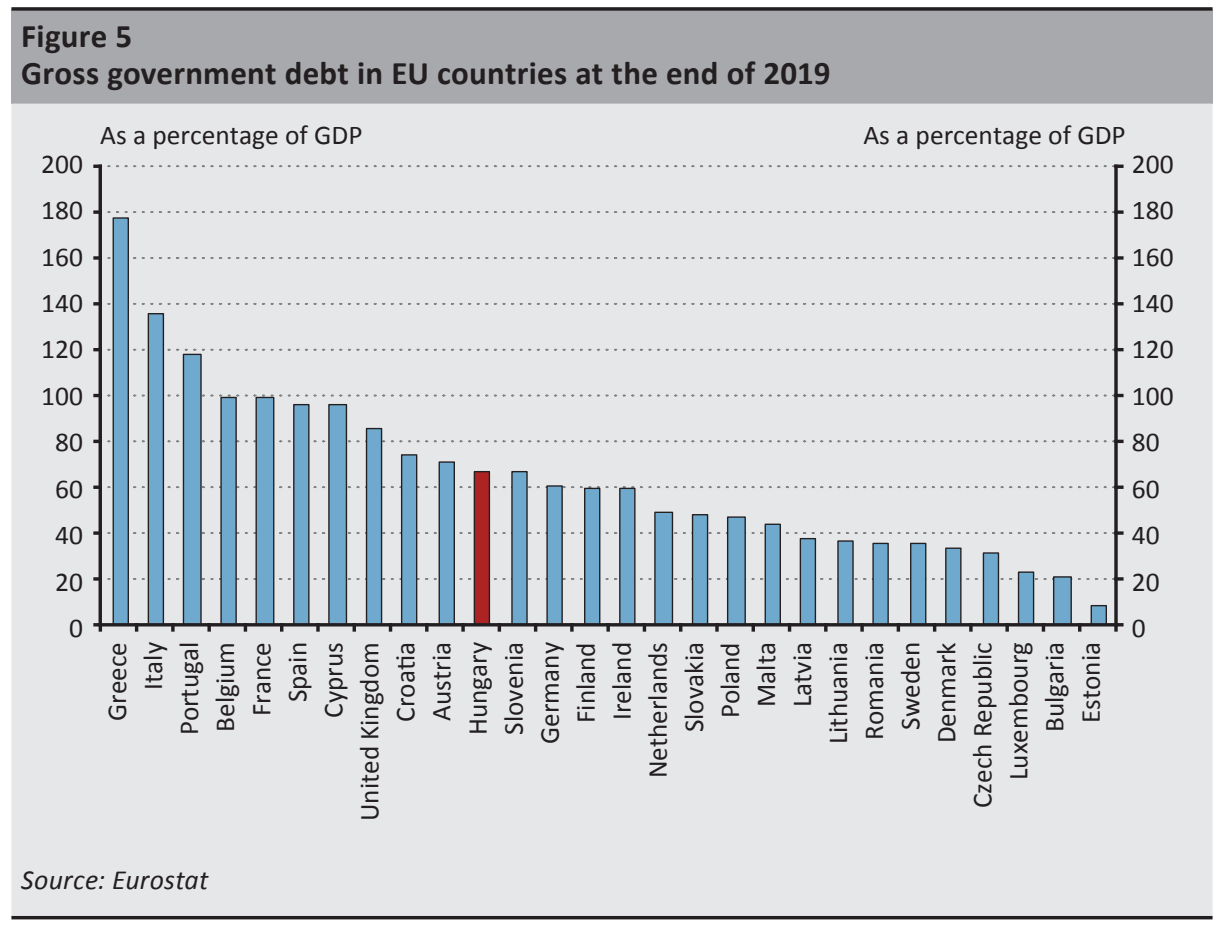


According to the estimates in this paper, interest expenditure declined by 0.4 percentage points in Hungary as a result of the debt reduction, which has continued steadily since 2011, a feat unparalleled in the EU. The greatest debt reduction occurred in Ireland and Malta in the period under review (Figure 6). When estimating the effect of the debt ratio on interest expenditure, the main factor taken into account was the change in government debt, and only a slight adjustment was used, for example taking into account the rapid increase or decrease in debt within the year and the change in the average term to maturity. As a result, the interest rate effect of the debt ratio correlated strongly with the underlying variable used, i.e. the change in the debt ratio (Figure 6).

\section{Figure 6 \\ Change in debt ratio and effect of the change in debt on interest expenditure, 2013- 2019}

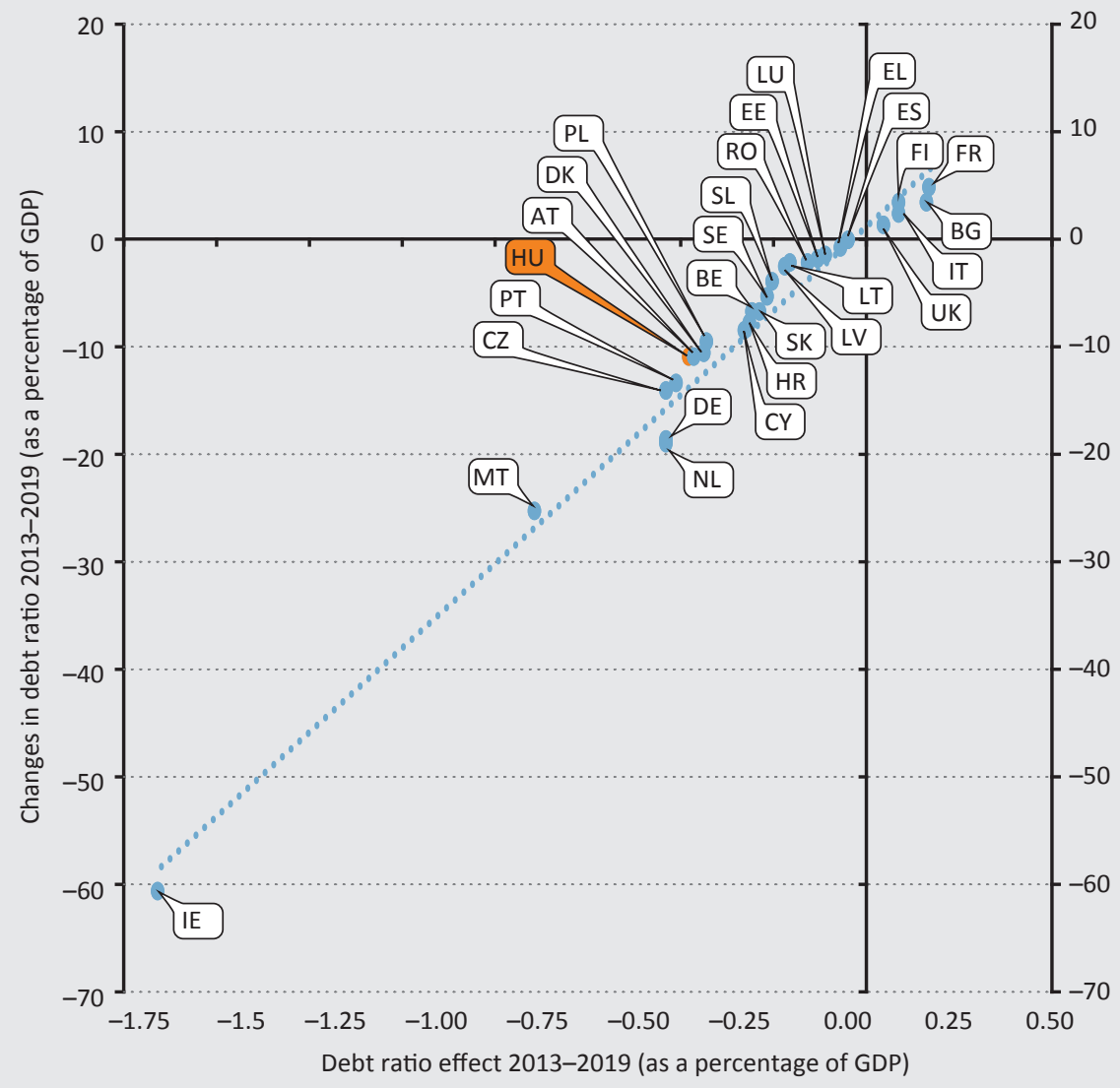

Note: We marked the countries with two-digit codes for the sake of transparency.

Source: Edited based on Eurostat, Bloomberg, ECB data 
Hungary is ranked seventh as regards the impact of government debt. There are 23 countries in total where the debt effect reduced interest expenditure in the period under review, while the impact of the debt ratio varies between -0.5 and +0.5 per cent of GDP, with the exception of the first two countries. An effect raising interest expenditure can be observed in five countries, but the decrease in yields and interest rates offset the expenditure growth in these countries too, so the interest expenditure ultimately did not climb there either.

In several countries, the decline in the debt ratio was influenced by strong economic growth. This effect was particularly strong in Ireland and Malta, so the debt ratio diminished the most in these two countries. In other countries, for example Germany and the Netherlands, the main reason behind the significant improvement in the debt ratio was not economic growth but the budget surplus derived from the disciplined fiscal policy, which curbed the growth of nominal debt.

\section{Effect of foreign currency debt on interest expenditure}

The overall effect of the foreign currency debt on interest expenditure is quite moderate, and it should be treated separately from the revaluation of foreign currency debt, which can be found in the debt ratio effect, because here the focus is on the change in the value of the given FX interest payment expressed in the local currency. In Hungary's case, this direct effect refers to how the fixed FX interest payments developed in forint terms.

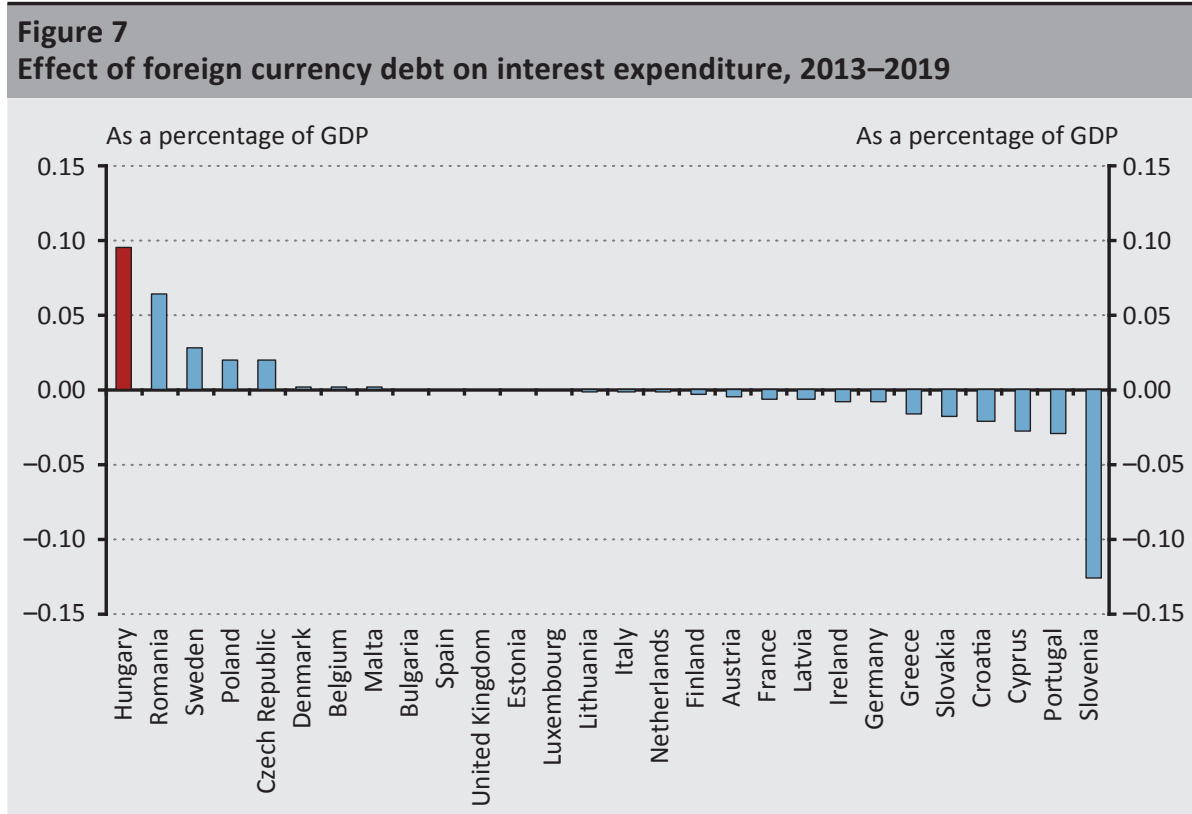

Source: Edited based on Eurostat, Bloomberg, ECB data 
The interest effect of foreign currency debt lifted interest expenditure by 0.1 percentage point in Hungary, which was the greatest additional interest burden growth in the EU. Figure 7 shows that several countries of the CEE region experienced this effect, since Hungary is followed directly by Romania in the ranking, and Poland and the Czech Republic are also close behind. Several Member States, especially in the euro area, were indebted in the common currency only, and in such cases the interest effect of the foreign currency debt is, accordingly, zero. The expenditure declined in the countries where the domestic currency appreciated against the currency in which the indebtedness occurred.

The main reason behind the large FX effect, which outstripped other countries in the region, is that in 2019 Hungary had the fourth greatest foreign currency debtto-GDP ratio among European Union Member States (Figure 8). However, in the EU countries with a higher foreign currency debt than Hungary, the exchange rate regime is much more rigid. In Croatia and Romania, the exchange rate against the euro moves within a tight band (stabilised arrangement), while in the even more rigid Bulgarian regime a currency board operates, in contrast to Hungary's floating exchange rate regime (IMF 2020).

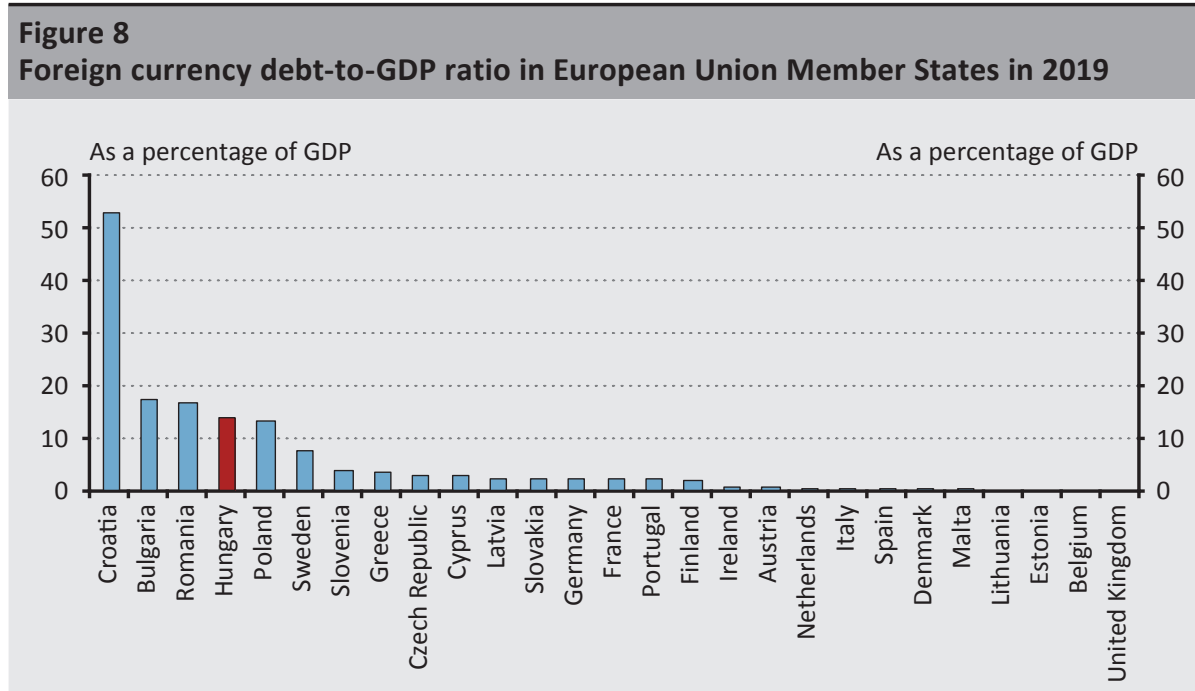


Impact of euro area accession on foreign currency ratio within government debt

In the case of several countries, the time series presenting the share of foreign currency debt show a slump in the year of joining the euro area. This is because the foreign currency debt of the countries joining the currency union was primarily denominated in euros in the years leading up to their euro area membership. The dip after the joining was the most marked in Baltic states that have a higher foreign currency ratio (60-80 percentage points), but in Cyprus and Slovenia the foreign currency debt of 20-30 per cent diminished to around zero. Of course, debt outstanding in dollars, Swiss francs, yen or other currencies remained foreign currency debt even after the euro was introduced.

However, euro area members have no independent monetary policy toolkit at their disposal that they could use as with their earlier, own currency. The euro area crisis that emerged from the 2008 global economic crisis showed in the southern peripheral countries of the euro area (Greece, Portugal, Italy, Spain) that the funding difficulties caused by being deprived of an independent monetary policy while being part of a suboptimal currency area with no common fiscal policy may offset the advantages derived from the reduction in foreign currency debt (Benkö 2013).

\section{Summary}

The study examined the development of the Hungarian budget's accrual-based interest expenditure in an international context. The analysis framework was provided by a decomposition method that helps break the change in interest expenditure down into factors, and this decomposition facilitated the establishment of the effects and macroeconomic developments that led to the reduction in expenditure. Moreover, the factors' relationship to underlying variables was also evaluated.

Among the European Union countries, Hungary recorded the second greatest drop in interest expenditure between 2013 and 2019, amounting to 2.2 per cent of GDP. Although the interest burden of government debt contracted in all EU countries, savings greater than in Hungary were only observed in Ireland. The total interest savings amounted to 9 per cent of GDP in Hungary in the period under review. Together with the primary budget surplus, these large savings created a positive debt spiral: the fall in interest expenditure helped reduce the debt ratio, while the diminishing debt reduced interest expenditure even more.

The decomposition of the change in interest expenditure into factors shows that within the European Union the yield and interest effect was the largest in 
Hungary (at 1.73 per cent of GDP), and it alone contributes around 80 per cent of the reduction in expenditure. The marked plunge in yields was facilitated by the central bank measures introduced in the low inflation environment (rate-cutting cycle, Self-Financing Programme, restructuring the central bank's toolkit), which was supported by Hungarian macroeconomic developments, the disciplined fiscal policy and the international environment.

The contraction in the debt ratio explains a fall in interest expenditure amounting to 0.4 per cent of GDP, which places Hungary seventh in the EU ranking, and this caused approximately 18 per cent of the total reduction in the expenditure. This decline is primarily attributable to the fact that Hungary's debt ratio has been steadily diminishing since 2011. As a result, the country's debt level was 13 percentage points lower than the EU average in 2019. In itself, the change in the debt ratio reduced interest expenditure in 23 countries and increased it in 5 in the period under review. Overall, interest expenditure did not surge even in places where debt grew, because in such cases the drop in yields offset the negative effect of indebtedness.

Foreign currency debt has a marginal effect on interest rates in most of the countries under review. In Hungary, the foreign currency debt itself caused an additional interest burden increase of 0.1 per cent, which means slightly higher interest savings could have been achieved with a lower foreign currency debt level. Several euro area countries have negligible or no foreign currency debt, therefore no such effect arose there.

All in all, the fact that interest expenditure in Hungary diminished considerably, even by EU comparison, is to a large extent explained by the fall in government securities market yields, facilitated by the coordination between the two main branches of economic policy - fiscal and monetary policy - strengthened further by the steadily declining trend of the debt ratio since 2011 , and held back only moderately by the negative effect of foreign currency debt.

\section{References}

Baksay, G. - Karvalits, F. - Kuti, Zs. (2012): The impact of public debt on foreign exchange reserves and central bank profitability: the case of Hungary. BIS Papers, No 67: 179-193. https://www.bis.org/publ/bppdf/bispap67l.pdf

Baksay, G. - Berki, T. - Csaba, I. - Hudák, E. - Kiss, T. - Lakos, G. - Lovas, Zs. - P. Kiss, G. (2013): Developments in public debt in Hungary between 1998 and 2012: trends, reasons and effects. MNB Bulletin, 2013(Special Issue): 14-22. https://www.mnb.hu/letoltes/ baksay-berki-csaba-hudak-kiss-lakos-lovas-pkiss.pdf 
Benkő, D.J. (2013): A Merkel-kormány válságkezelése a német belpolitika tükrében (The Merkel Cabinet's Crisis Management in view of German Domestic Policy). BA/BSc thesis, BCE Nemzetközi Tanulmányok Intézet (Institute of International Studies), Budapesti Corvinus Egyetem (Corvinus University of Budapest).

Blanchard, O. (1990): The Sustainability of Fiscal Policy: New Answers to an Old Question. OECD Economic Studies, 15(Autumn): 7-36.

Bundesbank (2017): The development of government interest expenditure in Germany and other euro-area countries. Monthly Report, July, Deutsche Bundesbank.

Csutiné Baranyai, J. - Lehmann, K. - Mérő, B. (2017): The ECB in new territory - „Whatever it takes"? In: Lehmann, K. - Palotai, D. - Virág, B. (eds.): The Hungarian Way - Targeted Central Bank Policy. MNB Book Series, Magyar Nemzeti Bank.

Das, U.S. - Papapioannou, M - Pedras, G. - Ahmed, F. - Surti, J. (2010): Managing Public Debt and Its Financial Stability Implications. IMF Working Paper WP/10/280, International Monetary Fund. https://doi.org/10.5089/9781455210879.001

ESM (2017): Evaluation Report. EFSF/ESM Financial Assistance, European Stability Mechanism. https://www.esm.europa.eu/sites/default/files/ti_pubpdf_dw0616055enn_ pdfweb_20170607111409_0.pdf. Downloaded: 6 April 2020.

Guscina, A. (2008): Impact of Macroeconomic, Political, and Institutional Factors on the Structure of Government Debt in Emerging Market Countries. IMF Working Paper WP/08/205, International Monetary Fund. https://doi.org/10.5089/9781451870633.001

Hemming, R. - Petrie, M. (2000): A Framework for Assessing Fiscal Vulnerability. IMF Working Paper WP/00/52, International Monetary Fund. https://doi. org/10.5089/9781451847246.001

IMF (2020): Annual Report on Exchange Arrangements and Exchange Restrictions 2019. International Monetary Fund, Washington, DC. https://www.imf.org/en/ Publications/Annual-Report-on-Exchange-Arrangements-and-Exchange-Restrictions/ Issues/2020/08/10/Annual-Report-on-Exchange-Arrangements-and-ExchangeRestrictions-2019-47102

Izák, V. (2009): Primary balance, public debt and fiscal variables in postsocialist members of the European Union. Prague Economic Papers, 18(2): 114-130. https://doi.org/10.18267/j. pep.345

Kicsák, G. (2015): A 2012-2015-ben bevezetett jegybanki intézkedések hatása az államháztartás finanszírozására (The Effect of the Central Bank Measures Introduced in 2012-2015 on the Financing of the General Government). Szakmai cikk (Article), Magyar Nemzeti Bank. https://www.mnb.hu/letoltes/15-06-29-kicsak-gergely-a-2012-2015ben-bevezett-jegybanki-intezkedesek-hatasa-az-allamhaztartas-finanszirozasara.pdf. Downloaded: 6 March 2020. 
Kicsák, G. (2016): Az EU-hitel utolsó részletének törlesztése egyszerre csökkentette az ország sérülékenységét és az adósságfinanszirozás költségét (The Repayment of the Last Instalment of the EU Loan Reduced both Hungary's Vulnerability and the Cost of Debt Financing). Szakmai cikk (Article), Magyar Nemzeti Bank. https://www.mnb.hu/letoltes/ kicsak-az-eu-hitel-utolso-reszletenek-visszafizetesemnbhonlapra.pdf. Downloaded: 6 March 2020.

Kicsák, G. (2017): Developments in Government Interest Expenditure for Hungary, 20002015. Financial and Economic Review, 16(1): 46-73. https://en-hitelintezetiszemle.mnb. hu/letoltes/gergely-kicsak.pdf

Lentner, Cs. (2015): Az új magyar állampénzügyi rendszer - történeti, intézményi és tudományos összefüggésekben (The New Hungarian Public Finance System - in a Historical, Institutional and Scientific Context). Pénzügyi Szemle (Public Finance Quarterly), 60(4): 458-472.

Matolcsy, Gy. (2019): A sikeres válságkezelés a 12 gazdasági fordulat tükrében (Successful Crisis Management in the Light of the Twelve Economic Turnarounds). Polgári Szemle (Civic Review), 15(1-3): 15-45. https://doi.org/10.24307/psz.2019.0903

Matolcsy, Gy. - Palotai, D. (2018): The Hungarian Model: Hungarian Crisis Management in View of the Mediterranean Way. Financial and Economic Review, 17(2): 5-42. http://doi. org/10.25201/FER.17.2.542

Matolcsy, Gy. - Palotai, D. (2019): Hungary Is on the Path to Convergence. Financial and Economic Review, 18(3): 5-28. http://doi.org/10.33893/FER.18.3.528

Panizza, U. (2008): Domestic and External Public Debt in Developing Countries. United Nations Conference on Trade and Development Discussion Paper No. 188. https://doi. org/10.2139/ssrn.1147669

Tóth, G.Cs. (2011): Adósságdinamika és fenntarthatóság (Debt Dynamics and Sustainability). Statisztikai Szemle (Hungarian Statistical Review), 89(12): 1242-1268.

Tóth, G.Cs. (2014): A költségvetés fenntarthatóságát mérő mutatók elörejelző képessége (The Forecasting Capacity of Indicators Measuring Budget Sustainability). Pénzügyi Szemle (Public Finance Quarterly), 2014(4): 544-561.

Turner, D. - Spinelli, F. (2012): Interest-rate-growth differentials and government debt dynamics. OECD Journal: Economic Studies, 2012(1): 103-122. http://dx.doi.org/10.1787/ eco_studies-2012-5k912k0zkhf8 


\section{Annex}

\section{Table 1}

Structure of the change in interest expenditure in 2013-2019 (percentage of GDP)

\begin{tabular}{|c|c|c|c|c|c|}
\hline & $\begin{array}{l}\text { Effect of } \\
\text { changes in } \\
\text { yields and } \\
\text { interest rates }\end{array}$ & $\begin{array}{c}\text { Effect of } \\
\text { change in the } \\
\text { debt ratio }\end{array}$ & $\begin{array}{l}\text { Effect of FX } \\
\text { debt on } \\
\text { interest rate }\end{array}$ & Other effects & $\begin{array}{c}\text { Change in } \\
\text { interest } \\
\text { expenditure }\end{array}$ \\
\hline Ireland & -1.43 & -1.66 & -0.02 & 0.11 & -3.00 \\
\hline Hungary & -1.73 & -0.40 & 0.09 & -0.15 & -2.20 \\
\hline Portugal & -1.56 & -0.43 & -0.05 & 0.24 & -1.80 \\
\hline Malta & -0.95 & -0.77 & 0.00 & 0.22 & -1.50 \\
\hline Italy & -1.14 & 0.10 & 0.00 & -0.36 & -1.40 \\
\hline Belgium & -0.92 & -0.25 & 0.00 & -0.13 & -1.30 \\
\hline Austria & -0.68 & -0.39 & -0.01 & -0.12 & -1.20 \\
\hline Spain & -1.06 & -0.02 & 0.00 & -0.12 & -1.20 \\
\hline Greece & -1.06 & -0.04 & -0.02 & -0.08 & -1.20 \\
\hline Poland & -0.65 & -0.36 & 0.02 & -0.11 & -1.10 \\
\hline Germany & -0.64 & -0.45 & -0.01 & 0.11 & -1.00 \\
\hline Denmark & -0.56 & -0.37 & 0.00 & -0.07 & -1.00 \\
\hline Lithuania & -0.85 & -0.16 & 0.00 & 0.11 & -0.90 \\
\hline France & -0.73 & 0.10 & -0.01 & -0.26 & -0.90 \\
\hline Croatia & -0.51 & -0.26 & -0.04 & -0.09 & -0.90 \\
\hline Cyprus & -0.71 & -0.27 & -0.03 & 0.11 & -0.90 \\
\hline Latvia & -0.78 & -0.17 & -0.01 & 0.16 & -0.80 \\
\hline Netherlands & -0.46 & -0.46 & 0.00 & 0.12 & -0.80 \\
\hline Slovenia & -0.62 & -0.20 & -0.14 & 0.16 & -0.80 \\
\hline Slovakia & -0.65 & -0.24 & -0.02 & 0.21 & -0.70 \\
\hline Romania & -0.68 & -0.12 & 0.05 & 0.14 & -0.60 \\
\hline Czech Republic & -0.39 & -0.45 & 0.01 & 0.24 & -0.60 \\
\hline United Kingdom & -0.42 & 0.06 & 0.00 & -0.24 & -0.60 \\
\hline Finland & -0.66 & 0.16 & 0.00 & 0.10 & -0.40 \\
\hline Sweden & -0.36 & -0.22 & 0.03 & 0.14 & -0.40 \\
\hline Luxembourg & -0.39 & -0.08 & 0.00 & -0.04 & -0.30 \\
\hline Estonia & -0.08 & -0.10 & 0.00 & 0.08 & -0.10 \\
\hline Bulgaria & -0.24 & 0.17 & 0.00 & -0.03 & -0.10 \\
\hline
\end{tabular}

